\title{
The DUTY TO DEFEND AND ITS APPLICABILITY IN Sexual Tort Cases: Perpetrators, InNOCent CO-INSUREDS AND THE IMPACT OF NON-MARINE UNDERWRITERS, LLOYD'S OF LONDON V. SCALERA
}

\author{
THOMAS P. O'LEARY'
}

\section{INTRODUCTION}

The increasing number of sexual assaults being reported has led to an increased focus on the law surrounding the liability of insurers in sexual assault cases. Insurers are questioning their obligation to defend and indemnify perpetrators of sexual assaults, the perpetrators' employers, and others who may face civil liability.

The recent decision of the Supreme Court of Canada in Non-Marine Underwriters, Lloyd's of London v. Scalera' directly addressed many of the issues likely to arise for an insurer in these circumstances, and it should be influential in consideration of most other potential coverage issues. With this recent case in mind, this article will examine the main issues relating to the liability insurer's duty to defend perpetrators of sexual assault, their employers, and other innocent co-insureds.

\section{General Principles of Liability Insurance - A Few Words}

Until recently, civil sexual assault cases were rare and those where a defendant sought indemnity or a defence from an insurer rarer still. Given this situation, older policies do not have specific exclusion clauses dealing with sexual assault, and such exclusions are still far from universal. In the absence of an exclusion or other policy provision dealing specifically with coverage in these circumstances, standardized policy provisions and exclusions will govern and will require interpretation and application by the court. Due to the general nature of such clauses, the fundamental principles of liability insurance law are likely to be at the forefront of a court's deliberations as to an insurer's defence and indemnity obligations.

Sometimes framed in terms of "reasonable expectations" or "public policy," these basic insurance principles are geared toward obtaining a sensible commercial result in the case at hand and enforcing the basic principle of uncertainty or risk that underlies all insurance. In Consolidated-Bathurst Export Ltd. v. Mutual Boiler \& Machinery Insurance Co. the Supreme Court of Canada provided some general guidance on policy interpretation, the majority stressing that sensible commercial results should be promoted where possible:

[L]iteral meaning should not be applied where to do so would bring about an unrealistic result or a result which would not be contemplated in the commercial atmosphere in which the insurance was contracted.... Similarly, an interpretation which defeats the intentions of the parties and their objective in entering into 
the commercial transaction in the first place should be discarded in favour of an interpretation of the policy which promotes a sensible commercial result. ${ }^{2}$

Brown and Menezes also address these fundamental concepts, stating:

Insurance is a mechanism for transferring fortuitous contingent risks. Losses that are neither fortuitous nor contingent cannot economically be transferred because the premium would have to be greater than the value of the subject matter in order to provide for marketing and adjusting costs and a profit for the insurer. It follows, therefore, that even where the literal wording of a policy might appear to cover certain losses, it does not, in fact, do so if (1) the loss is from the inherent nature of the subject matter being insured, or (2) it results from the intentional actions of the insured.'

This passage was quoted with favour by the Supreme Court of Canada in Scalera ${ }^{4}$ (discussed in detail below). Iacobucci J. in Scalera also stated that in construing coverage, "one must always remember that insurance is presumed to cover only negligence, not intentional injuries."

Brown and Menezes continue on to state, lest there be confusion on the point, that

[a]s a simple rule of interpretation uncomplicated by other considerations, it ought to be an uncontroversial corollary of the proposition that insurance only transfers fortuitous or contingent risks....

The limit to the implied rule is that the result be intended, even if it is subsequently regretted. ${ }^{6}$

This latter passage was explicitly endorsed by the Manitoba Court of Appeal in Acklands Ltd. v. Canadian Indemnity Company. ${ }^{7}$ Though not quoted, the passage is also consistent with the Supreme Court of Canada reasons in Scalera.

In dealing with defence and coverage obligations of an insurer in civil sexual assault cases, the author submits that it is this fundamental principle of risk or uncertainty that is at stake, and which should guide the analysis of coverage issues. In short, the result should never countenance a defence or coverage to any insured where the alleged wrongdoing of that insured is intentional in the sense that it was meant to cause injury to the victim.

\section{Duty to Defend - General Principles}

Liability insurance is designed to indemnify the insured for losses covered by the policy and to provide a defence for allegations which may give rise to a duty to indemnify. In rare cases, the duty to defend is not restricted to such claims. These rare cases must be analyzed on an individual basis and are beyond the scope of this article.

(1979), 112 D.L.R. (3d) 49 at 58 [hereinafter Consolidated-Bathurst].

C. Brown \& J. Menezes, Insurance Law in Canada, 2nd ed. (Toronto: Carswell, 1991) at 125-26. Supra note 1 at 590 , para. 68.

Ibid. at 599, para. 86.

Supra note 3 at 126.

[1985] 4 W.W.R. 71 at 74, aff'g [1984] 4 W.W.R. 764 (Man. Q.B.) [hereinafter Acklands]. 
The duty to defend is often said to be broader than the duty to indemnify because it includes obligations to defend allegations which may be included within the scope of coverage. Prior to Scalera, the basic principles regarding the duty to defend were reflected in the leading and oft quoted cases of Bacon v. McBride ${ }^{8}$ and Nichols v. American Home Assurance Co. ${ }^{9}$ In Bacon the British Columbia Supreme Court held that the duty to defend arises from the pleadings of the plaintiff and not the opinion of the insurer as to the validity of the claim:

The pleadings govem the duty to defend — not the insurer's view of the validity or nature of the claim or by the possible outcome of the litigation. If the claim alleges a state of facts which, if proven, would fall within the coverage of the policy the insurer is obliged to defend the suit regardless of the truth or falsity of such allegations. If the allegations do not come within the policy coverage the insurer has no such obligation.... In this respect the duty to defend may well be broader than the insurer's obligation to indemnify the insured for liability imposed by law. ${ }^{10}$

The notion that the duty to defend is broader than the duty to indemnify was echoed in Nichols where the Supreme Court of Canada stated:

At the same time, it is not necessary to prove that the obligation to indemnify will in fact arise in order to trigger the duty to defend. The mere possibility that a claim within the policy may succeed suffices. In this sense, as noted earlier, the duty to defend is broader than the duty to indemnify."

Cases interpreting these principles have left considerable uncertainty about the scope of allegations that may be covered. For example, would any arguable issue of policy interpretation as to the scope of coverage force an insurer to defend? Or is it up to the court to resolve questions on the scope of coverage when considering the duty to defend? Counsel for defendants seeking a defence may try to blur the ambit of coverage in order to gain a defence on the basis that coverage cannot be precisely determined. The other popular line of attack for insureds has been to suggest that vague pleadings and the plaintiff's characterization of the cause of action (however unrealistic) suffice to establish a possibility of coverage for which a defence is owed. The reasons in Scalera provide assistance to the insurer in respect of both types of argument.

In Scalera a defence was sought by an alleged perpetrator of sexual assaults under his homeowner's policy, which contained a general liability section. Iacobucci J. (though writing minority reasons, he wrote for the unanimous panel on these issues) reiterated that the duty to defend arises when there is a possibility that the insurer will have to indemnify. ${ }^{12}$ He clarified that this means that "[a]bsent specific language to the contrary, the duty to defend is broader than the duty to indemnify only in so far as it extends to groundless, false or fraudulent claims."13 By stating that this is the only sense in which

(1984), 6 D.L.R (4th) 96 [hereinafter Bacon].

(1990), 68 D.L.R. (4th) 321 [hereinafter Nichols].

Supra note 8 at 99.

Supra note 9 at 327.

Supra note 1 at 581, para. 49.

Ibid. at 594, para. 76. 
the duty to defend extends beyond indemnity, Iacobucci J. suggests that a court considering the duty to defend must make a definite determination as to the scope of coverage afforded, instead of awarding a defence based on some alleged vagueness or uncertainty as to coverage. This should be viewed as a sensible approach in that the court determining the duty to defend has no logical reason to defer the issue of scope of coverage to a later time. It is not a situation where later evidence will clarify the issue. At the defence stage, a difficulty in interpreting the true ambit or scope of coverage should never, by itself, be considered as going to indicate a "possibility" of coverage for which a defence is required. The court must interpret the policy and rule definitively on the scope of coverage at this juncture.

Iacobucci J. went on to set out a three part test for determining whether or not a given claim could trigger indemnity and thus give rise to a duty to defend. The first two steps deal with dissecting the true nature of the claim pleaded. In the context of sexual torts, this will usually focus on whether the facts alleged in the pleadings potentially involve negligence or are restricted to intentional acts. The third step in the test requires an analysis of the cover provided and the application of such to the facts pleaded:

First a court should determine which of the plaintiff's legal allegations are properly pleaded. In doing so, courts should consider only the facts pleaded and are not bound by the legal labels chosen by the plaintiff. A plaintiff cannot change an intentional tort into a negligent one simply by choice of words, or vice versa.

At the second stage, having determined what claims are properly pleaded, the court should determine if any claims are entirely derivative in nature. The duty to defend will not be triggered simply because a claim can be cast in terms of both negligence and intentional tort. If the alleged negligence is based on the same harm as the intentional tort, it will not allow the insured to avoid the exclusion clause for intentionally caused injuries.

Finally, at the third stage the court must decide whether any of the properly pleaded, non-derivative claims could potentially trigger the insurer's duty to defend. ${ }^{4}$

The second stage of the test is the only element of the analysis that is new. The first and third stages comprise the traditional two part test that has been used in determining the duty to defend for many years, recent cases almost universally citing Bacon or Nichols, or both, as authority for such. ${ }^{15}$ The decision in Scalera is significant in that it adds a third element to the test and adds clarity to the application of the other parts of the test. This three stage test and its application to sexual torts is analyzed in greater detail below.

is lbid. at 582, paras. 50-52.

Bacon, supra note 8; Nichols, supra note 9. See also Continental Insurance Co. v. Diamet Minerals Lid. (1996), 20 B.C.L.R. (3d) (B.C.C.A.); Wellington Guarantee v. Evangelical Lutheran Church in Canada (1996), 35 C.C.L.I. (2d) 164 (B.C.C.A.). 


\section{Duty to Defend - Civil Sexual Assault Claims}

\section{A. The Pleadings}

The first step in the process set forth in Scalera is to determine which of the plaintiff's legal allegations are properly pleaded. Most policies have a number of mechanisms (discussed below) to safeguard the principle of risk and preclude cover for intentionally caused losses. These mechanisms include requirements for an "accident" to trigger coverage as well as exclusion clauses for intentional acts. Usually, plaintiffs in sexual tort cases allege "negligence" in an attempt to circumvent these types of provisions and gain access to some insurance money.

The decision in Scalera seemed largely directed toward limiting this practice and any effectiveness it might have enjoyed. With respect to the first stage of the test, the Court repeatedly stressed that it is only the facts pleaded, not characterizations of them in the pleadings, that are relevant. Neither party should be at the whim of an inventive or purposeful third party pleader. This qualifies the ability of the plaintiff to allege "negligence" and thus bring the claim into the realm of the defendant's insurance coverage. It is important to note at this stage that one must not attempt to determine the merit of any of these factual allegations but consider only whether the facts pleaded could support the plaintiff's legal allegations. Iacobucci J. quoted from Peerless Insurance Co. v. Viegas: ${ }^{16}$

The fact that the allegations in that complaint are described in terms of "negligence" is of no consequence. A plaintiff, by describing his or her cat to be a dog, cannot simply by that descriptive designation cause the cat to bark."

He went on:

To be somewhat more prosaic, when determining the scope of the duty to defend, courts must take the factual allegations as pleaded, but then ask which of the plaintiff's legal claims could potentially be supported by those factual allegations. This is clear from Bacon, supra, at page 99 where the court limited the duty to defend to cases where the "claim alleges a state of facts which, if proven, would fall within ... coverage. ${ }^{18}$

The Court then proceeded to analyze the pleadings in Scalera to determine the nature of the causes of action that could be supported by the facts alleged. The pleadings characterized the cause of action under the following torts: (a) sexual battery; (b) negligence; (c) negligent misrepresentation; and (d) breach of fiduciary duty. While individual pleadings will differ, these causes of action (or some of them) will generally form the basis of the pleading in a sexual tort claim. 


\section{SEXUAL BATTERY}

The Court first considered the relatively new tort of sexual battery. Battery was said to be defined by the infliction, without consent, of harmful or offensive force on the victim. No intent to injure is necessary to prove the tort. It was noted that intentional battery, like other intentional torts, generally only requires an intent to cause the direct physical consequences of one's act, namely, an offensive touching. It is not necessary that the perpetrator foresees the actual harm resulting or knows that the intended consequences are an infringement on the legal rights of the victim.

The perpetrator in Scalera argued that cover existed for all but intentionally caused harm. He also argued that it was possible for him to have committed (non-consensual) sexual battery but still not have intended the resulting harm, thus creating the possibility of insurance coverage. The Supreme Court of Canada disagreed on this latter point. The reasoning is critical to understanding why no coverage will exist for a defendant accused of sexual assault. The Court saw lack of consent as defining the tort and considered that consent, insofar as it relates to the tort of sexual battery, is an objective standard. This objective standard recognizes that unlike criminal law where mens rea prevails, the touchstone of liability in civil tort law is that of a reasonable person. If a reasonable person would have believed consent was present, consent will be objectively established. If not, no consent can be found, and the lack of consent itself establishes that the conduct alleged, the physical contact, is "harmful or offensive." Though McLachlin J., (as she then was) writing for the majority, held that consent was a defence to be established by the defendant and the minority judgment of Iacobucci J. considered lack of consent to be an element of the offence to be proven by the plaintiff, both the majority and the minority reasons agreed that consent or lack thereof must be judged on an objective basis.

By extension, both minority and majority reasons are, therefore, clear that a "negligent" belief in consent is not relevant to the coverage issue. The majority reasons of McLachlin J. (as she then was) state:

The logic is simply that either the act must have been consensual or not consensual. If it was not consensual, the policy does not apply because neither the insured nor the insurer contemplated coverage for non-consensual sexual activities. If it was consensual, then there is no battery and no claim for recovery. ${ }^{19}$

The minority reasons also considered the issue:

If the consent of the plaintiff was present, then no claim of sexual battery is made out since the conduct of the appellant would not be regarded objectively as being harmful or offensive, and therefore the duty to indemnify would not arise because the plaintiff's claim has no possibility of success.... On the other hand, if consent of the plaintiff is absent, the conduct of the appellant would be actionable as an intentional tort of sexual battery. ${ }^{20}$ 
The Court was unanimous in concluding that the underlying facts pleaded in Scalera made out claims for sexual battery and that, by its very nature, the tort of sexual battery imported an intention to cause injury on the part of the perpetrator. The majority reasons of McLachlin J. (as she then was) stated this conclusion as follows:

[W] here there is an allegation of sexual battery, courts will consider as a matter of legal inference that the defendant intended harm for the purpose of construing exemptions of insurance coverage for intentional injury.

This presumption of intent to harm does not depend on requiring the plaintiff to prove that the defendant knew or ought to have known that the plaintiff was not consenting to the sexual contact. Rather, the presumption flows from the allegation in the pleadings of battery of a sexual nature."

In other words, in order to be actionable, sexual battery requires that the defendant knew or ought to have known that the plaintiff did not consent to the sexual contact. Unless such is disproven by the defendant (being a defence to the entire claim) the court will infer an intent to cause harm.

Though placing the burden of proof regarding consent on the plaintiff rather than the defendant, the minority reasons of Iacobucci J. are also relevant to understanding this presumption of intent. He stated:

I do not think the harm is any less real just because the victim has been coerced into sex by mental as opposed to physical means. It can hardly be disputed, I think, that any type of non-consensual sex clearly evinces an intent to harm the victim thereof. ${ }^{22}$

These statements should meet any future arguments to the effect that a perpetrator, despite lack of objective consent, did not intend to cause harm when committing sexual battery.

\section{NEGLIGENT BATTERY}

After dealing with sexual battery, Scalera also addressed whether the pleading in that case properly alleged negligent battery. The Court was unanimous that such a cause of action could not arise on the basis of a negligent belief by the perpetrator in the consent of the victim. This flows from the recognition that consent in these circumstances is an objective standard. The perpetrator's belief is therefore irrelevant.

The majority reasons of McLachlin J. (as she then was) addressed negligent battery in only a passing manner. ${ }^{23}$ In the minority reasons, Iacobucci J. stated that negligent battery could only be relevant to the duty to defend analysis in a sexual tort claim if the pleadings alleged that the perpetrator harmed the plaintiff by disregarding a foreseeable risk of physical contact, even though the contact was neither desired nor substantially 
certain to occur. ${ }^{24}$ This type of allegation was not made in Scalera and is very unlikely to be made in a sexual tort action.

\section{NEGLIGENT MISREPRESENTATION}

Negligent misrepresentation was also considered a potential cause of action based on the pleadings in Scalera. It is not unusual for a plaintiff in a sexual tort action to allege that he or she was coerced into seemingly consensual sexual activity as a result of misrepresentation by the perpetrator as to the legitimacy or propriety of such activity. For example, this type of allegation might commonly be made against the backdrop of a counselling relationship or in an employment situation. The Supreme Court of Canada did not specifically address whether such allegations were properly pleaded in Scalera, nor did it discuss circumstances in which they might be properly pleaded in another case. This type of analysis apparently was not considered necessary given the application of the second part of the test for duty to defend. In any event, there is no reason to believe that such allegations could not be properly pleaded in the normal course.

\section{BREACH OF FIDUCIARY DUTY}

Finally, the tort of breach of fiduciary duty was considered. This was alleged in the Statement of Claim in Scalera and is commonly alleged in sexual torts, particularly where there is an employment or counselling relationship between perpetrator and victim. Iacobucci J. commented with respect to this cause of action:

\footnotetext{
Looking beyond the label to what is actually alleged in the pleadings, and without expressing any opinion on the validity of a fiduciary duty claim on the facts of this appeal, there are no facts pleaded to suggest that the breach of fiduciary duty was anything but intentional in nature. The appellant was alleged to have intentionally seduced the plaintiff, and whether or not this can be characterized as a fiduciary duty claim, any injuries resulting therefrom were caused intentionally. ${ }^{25}$
}

The gist of this reasoning seems to be that where the physical contact alleged to constitute the actionable breach of duty was in itself intentional, a breach of fiduciary duty claim arising from that contact stands on the same footing as any other intentional tort claim. That is, a breach of fiduciary duty, like a breach of contract, can be either intentional or negligent. Any breach of fiduciary duty based on sexual acts and the resulting harm must seemingly be intentional due to the lack of consent that must exist in order for those acts to be actionable. As with battery, consent (through the medium of estoppel) is a defence to any breach of fiduciary duty claim. The same logic employed by the court in dealing with sexual battery should, therefore, also apply to breach of fiduciary duty claims.

The Court in Scalera apparently did not consider it necessary to further analyze this cause of action given the application of the second part of the three part duty to defend 
analysis. As with negligent misrepresentation, there is no reason to believe that such allegations could not be properly pleaded in the normal course.

\section{B. Derivative Claims}

The second part of the three part test endorsed in Scalera is to determine if any pleaded claims are "derivative" in the sense that they should be considered as one with another pleaded claim. This concept is new to Canadian law, but has some history in American jurisprudence. It seems directed to recognizing that, in any intentional tort, there may be negligent aspects of the wrongdoer's conduct. For example, a perpetrator might negligently but genuinely believe (however bizarre it may sound) that sexual assaults committed are "for the victim's own good." There will invariably be factual allegations of intentional tort in sexual tort actions. Given the prevailing practice of pleading causes of action broadly and alternatively, there may also be properly pleaded claims that the sexual tort constituted or was induced by negligence, negligent misstatement, breach of fiduciary duty, breach of contract, or involved harassment or breach of confidence. A specific claim will be "derivative" if both the intentional tort and that pleaded claim arise from the same acts and cause the same harm.

In Scalera The Supreme Court of Canada endorsed the following approach in such cases:

Having construed the pleadings, there may be properly pleaded allegations of both intentional and nonintentional tort. When faced with this situation, a court construing an insurer's duty to defend must decide whether the harm allegedly inflicted by the negligent conduct is derivative of that caused by the intentional conduct. In this context, a claim for negligence will not be derivative if the underlying elements of the negligence and of the intentional tort are sufficiently disparate to render the two claims unrelated. If both the negligence and intentional tort claims arise from the same actions and cause the same harm, the negligence claim is derivative, and it will be subsumed into the intentional tort for the purposes of the exclusion clause analysis. If, on the other hand, neither claim is derivative, the claim of negligence will survive and the duty to defend will apply. Parenthetically, I note that the foregoing should not preclude a duty to defend simply because the plaintiff has pleaded in the alternative. As Pryor, "The Stories We Tell: Intentional Harm and the Quest for Insurance Funding", supra, points out at p. 1752, "[p]laintiffs must have the freedom to plead in the alternative, to develop alternative theories, and even to submit alternative theories to the jury". A claim should only be treated as "derivative", for the purposes of this analysis, if it is an ostensibly separate claim which nonetheless is clearly inseparable from a claim of intentional tort. ${ }^{25}$

This approach was justified on two bases. First, insurance is presumed to cover only negligence, not intentional injuries. Second, plaintiffs should be discouraged from manipulative and vague pleadings. The approach mandated in Scalera should make it fruitless for plaintiffs to try to characterize intentional torts as negligence or vice versa.

To illustrate the proper application of this part of the test in sexual tort cases lacobucci J. looked to American case law dealing with sexual torts, where courts have traditionally 
denied coverage for claims of negligent battery, negligent misrepresentation, negligent infliction of emotional distress, negligent interference with familial relations, and any other claims of "negligence." Specifically, the example of Houg v. State Farm Fire and Casualty $\mathrm{Co}^{27}$ was cited. In that case a church pastor was alleged to have sexually abused an adult parishioner. The parishioner alleged negligent counselling as part of the claim against the pastor. The Court of Appeal of Minnesota found no duty to defend because any negligent counselling was felt to be so intertwined with the insured's sexual exploitation of a psychologically dependent person as to be inseparable. In other words, "the negligent counselling claim was merely derivative of the sexual assault. The fact that there may have been negligent aspects of the [defendant's] conduct [could] not change the essentially intentional nature of his conduct." ${ }^{28}$ Other American cases cited denied defences for claims of "negligent" child molestation, seduction of a child by a teacher, and repeated sexual assaults. Pleas of this type were viewed as "a transparent attempt to trigger insurance coverage by characterizing allegations of tortious conduct under the guise of "negligent activity" 29 or as a "disingenuous attempt to create a factual dispute." ${ }^{30}$ Given these illustrations, it is difficult to conceive of how any plea of "negligence" against a perpetrator in the sexual tort context could trigger a duty to defend.

Keeping in mind the test for such a "derivative" claim is that it must arise from the same conduct and result in the same harm as an intentional tort, the Court in Scalera then set about analyzing the pleaded allegations of negligent misrepresentation and breach of fiduciary duty. The Court held that even if negligent misrepresentation were properly pleaded, such would be entirely derivative of the intentional sexual battery in this case. Though the analysis on the point is rather sparse, lacobucci J. noted that the alleged misrepresentations were said to be designed to seduce the plaintiff and convince her to engage in sexual activity with the perpetrator, the same activity alleged to have resulted in damages. As such, lacobucci J. reasoned, they were entirely subservient to the sexual battery in that they arose from the same actions and caused the same harm. He wrote:

The plaintiff has clearly alleged intentional conduct by the appellant. Without ruling out the possibility that the plaintiff's pleadings could support claims of both intention and negligence as a matter of tort law, I conclude as a matter of insurance law that the negligent claims are subsumed for the purposes of the exclusion clause. The allegations of negligent misrepresentation are derivative of the intentional sexual assault claims, and cannot trigger the duty to defend. ${ }^{31}$

Though not explored further in Scalera, the key to understanding this passage seems to be remembering the critical role that the issue of consent plays in sexual torts. Any misrepresentation inducing apparent consent is relevant or actionable only insofar as it goes to vitiating that apparent consent. Keeping in mind that consent is objective and based on the standard of the reasonable person, it makes sense that any negligent misrepresentations be considered derivative of the intentional tort. After all, if the

481 N.W. 2d 393 (Minn. App. 1992).

Supra note 1 at 600 , para. 88.

Ibid. at 601 , para. 88.

Ibid.

Ibid. at 622, para. 130. 
misrepresentation was not reasonably (i.e., non-negligently) believed by the perpetrator, the apparent consent induced by that misrepresentation could not objectively exist. If objective consent was induced by a misrepresentation that was not negligent, no tort has taken place, and no duty to defend could arise.

With respect to breach of fiduciary duty, the Court also found such allegations to be entirely derivative of the intentional sexual assault claims. Such claims were said to have arisen from the same actions and resulted in the same harm as the intentional sexual battery. Again, the reasoning is brief. However, the basis for holding that these allegations are derivative to the sexual battery seems clear. Though an intentional tort might also constitute a breach of a fiduciary or other duty toward the victim, this can not assist the perpetrator in obtaining insurance coverage for his or her actions. The claims arising from non-consensual sexual activity are, by their very nature, claims for intentionally caused harm regardless of what cause of action may be created thereby.

\section{POSSibility Of COVerage - The Perpetrator}

It is notable that the vast majority of American case law dealing with perpetrators seeking a defence conclude that no coverage is available to a perpetrator, usually on the basis of an exclusion for intentional acts or for injury caused intentionally by the insured. Most Canadian cases have reached the same conclusion. The only Canadian case that seems to go against this trend is J.A.S. v. Gross. ${ }^{32}$ Although it is not entirely clear from the reasons, the decision to award an alleged perpetrator of a sexual assault a partial defence seems to be based on the view that a sexual assault could still give rise to claims in negligence. If that is indeed the basis for the decision, it seems to be in error in light of the result in Scalera. In any event, J.A.S. v. Gross is currently under appeal.

The reasons in Scalera feature a number of strong statements suggesting that the alleged perpetrator of a sexual assault will not be entitled to a defence or indemnity from an insurer except where the policy clearly and explicitly provides for such. It is suggested here that such statements were not meant to establish a principle of law as to interpretation against the insured but to recognize a practical reality. Specifically, the entitlement of a perpetrator to a defence or indemnity from an insurer flies so clearly in the face of the very basic principles of risk and uncertainty underlying insurance that a court is very unlikely to find such obligations in any insurance policy. There are a number of common liability policy provisions that could be utilized to yield this result. The most prominent of these are analyzed below.

\section{1. "ACCIDENT"}

The first potential argument for an insurer is based on the requirement of an "accident" in many liability policies. Sometimes policies are triggered by an "accident." More often, policies require an "occurrence," which is in turn defined to require, or at least include an "accident." For example, the definition of occurrence in the standard Commercial 
General Liability ("CGL") policy is "an accident, including continuous or repeated exposure to substantially the same general harmful conditions." ${ }^{33}$ Another common wording provides that "'Occurrence' means an accident including injurious exposure to conditions which results in bodily injury or property damage neither expected nor intended from the standpoint of the insured.".34

While the term is not normally defined in the policy, Canadian courts have defined "accident" as something unintended or unexpected from the standpoint of the insured..$^{35}$ Insurers might effectively argue that sexual assault should not be covered because it is not an "accident," being both intentional and foreseeable by the insured perpetrator. This argument would appear to have strong support in case law and in common sense.

The holding in Scalera that, by definition, the perpetrator of a sexual battery is held to have intended harm to the victim should be the keystone to any argument on this issue. It seems axiomatic that when one takes actions with an intent to cause injury, the injury so caused is not the result of an "accident." Such injury could not be "unexpected" or "unintended," and, therefore, sexual torts cannot be considered "accidents" within the meaning of liability insurance coverage.

In some cases, the policy wording will not require an accident as a condition of coverage. For example, "occurrence" will be defined as perhaps including, but not requiring, an accident. In such cases, one must look to other portions of the policy to place sexual torts outside the realm of coverage or attempt to rely on interpretive principles to infer that the occurrence definition still requires that the injury be "unexpected" or "unintended."

\section{LIABILITY IMPOSED BY LAW}

The wording of most liability coverage, whether in a CGL policy, professional liability policy, homeowners policy or otherwise, provides that the indemnity obligation is only triggered by "liability imposed by law" on an insured. Though rarely considered to be a means of safeguarding the principle of uncertainty, this phrase has been utilized in this fashion in at least one appellate level decision. In Acklands ${ }^{36}$ the Manitoba Court of Appeal endorsed the view that the phrase "liability imposed by law" implies that such liability must arise through unintentional conduct. This case arose out of a wrongful dismissal, with the insured employer seeking indemnity for the damages it was found liable to pay. The Manitoba Court of Appeal endorsed the view that "liability imposed by law" excluded this claim and that it would exclude all claims for indemnification arising from the intentional actions of the insured. Wright J. of the Manitoba Court of Queen's Bench, whose reasoning was affirmed on appeal, stated this principle as follows: "[t]he

The definition of occurence is taken from Commercial General Liability Form IBC 2100 (March 2000).

G. Hilliker, Liability Insurance Law in Canada, 2d ed., (Toronto: Butterworths, 1996) at 136; H.A. Sandstone, The Comprehensive General Liability Policy: The Insuring Intent (Toronto: Butterworths, 1990) at 95.

Mutual of Omaha Insurance v. Stats (1978), 87 D.L.R. (3d) 169 (S.C.C.).

Supra note 7. 
phrase 'liability imposed by law' implies liability which arises upon the happening of a fortuitous event or contingency which the insured or the other party has not intended or agreed will occur." 37

At both levels, the court quoted Brown and Menezes ${ }^{38}$ as correctly stating the fundamental principle of insurance to the effect that only fortuitous or contingent risks can be covered.

The rationale for implying the requirement of unintentional injury to the phrase "liability imposed by law" is not explained in Acklands, though one can surmise that it is based in the use of the word "imposed." This word could be considered to import a lack of intention or wilfulness on the part of the insured to do the act that creates liability. Liability arising from intentional injury would thus not be "imposed" or forced on the insured, but voluntarily assumed or accepted by the insured by virtue of willful and deliberate acts.

Two recent British Columbia Court of Appeal cases have touched on the issue and at first glance might seem to contradict Acklands. In both Cultus Lake Park v. Gestas Inc. ${ }^{39}$ and Surrey (District) v. General Accident Assurance ${ }^{40}$ the Court seemed to endorse the view (though only in obiter) that the phrase "liability imposed by law" includes liability imposed by a court judgment based on any cause of action. However, in neither case was Acklands explicitly rejected. Indeed, in Cultus the Court specifically accepted that Acklands involved "compelling reason" for limiting the meaning of the phrase to exclude intentionally caused harm. ${ }^{41}$ As such, the law in this respect as expressed in Acklands seems fairly certain.

\section{3. "INSURED"}

Liability coverage for business and charitable enterprises often extend coverage directly to employees when acting "within the scope of their employment" or on similar terms. This terminology mimics the standard test for vicarious liability of an employer for acts of an employee. Acts of an employee will be considered to be within the scope of employment when they are authorized by the employer (which will rarely, if ever, be at issue in the context of sexual torts) or where they are unauthorized but so closely connected with acts that the employer has authorized that they may be regarded as modes, albeit improper modes, of doing an authorized act. ${ }^{42}$ The proper approach to the issue of vicarious liability was recently explained in two Supreme Court of Canada decisions dealing with sexual torts, Bazley v. Curry ${ }^{43}$ and Jacobi v. Griffiths. ${ }^{44}$ Though use of the

Ibid. at 766.

Supra note 3.

(1996), 15 B.C.L.R (3d) 89 [hereinafter Cultus].

(1996), 35 C.C.L.I. (2d) 154.

Supra note 39 at 97.

Canadian Pacific Rwy. Co. v. Lockhart, [1942] A.C. 591 at 599 (P.C.).

[1999] 2 S.C.R. 534 [hereinafter Bazley].

[1999] 2 S.C.R. 570 [hereinafter Jacobi]. 
phrase "scope of employment" was disapproved of by the Court as being unhelpful, ${ }^{45}$ these cases should still determine the approach to interpreting that phrase in the insurance context. They are summarized below. The purpose of such, is to alert the reader that jobrelated sexual torts may not always be considered within the scope of employment and that the particular facts of each case will be closely examined in determining this question.

The two cases directed that the issue of vicarious liability for unauthorized intentional conduct be determined in two steps. First, the court

should determine whether there are precedents which unambiguously determine on which side of the line between vicarious liability and no liability the case falls. If prior cases do not clearly suggest a solution, the next step is to determine whether vicarious liability should be imposed in light of the broader policy rationales behind strict liability. ${ }^{46}$

The underlying policy rationales were identified as: "1) provision of a just and practical remedy for the harms; and 2) deterrence of future harm." 47

Taken together, the Bazley and Jacobi cases direct that where case law is indeterminate vicarious liability (or the "scope of employment" issue) for an employee's unauthorized intentional wrong, such as a sexual battery, should be approached as follows:

[1.] The fundamental question is whether the wrongful act is sufficiently related to conduct authorized by the employer to justify the imposition of vicarious liability. Vicarious liability is generally appropriate where there is significant connection between the creation or enhancement of a risk and the wrong that accrues therefrom, even if unrelated to the employer's desires."

[2.] The enterprise and employment must not only provide the locale or the bare opportunity for the employee to commit his or her wrong, it must materially enhance the risk, in the sense of significantly contributing to it, before it is fair to hold the employer vicariously liable.... Incidental connections to the employment enterprise, like time and place (without more), will not suffice.9

[3.] In determining the sufficiency of the connection between the employers creation or enhancement of the risk and the wrong complained of, subsidiary factors may be considered. These may vary with the nature of the case. When related to intentional torts, the relevant factors may include, but are not limited to, the following:

(a) the opportunity that the enterprise afforded the employee to abuse his or her power;

Bazley, supra note 43 at 559.

Ibid. at 545.

lbid. at 552 .

Ibid. at 559 [emphasis in original].

Ibid. at 558-59 [emphasis in original]. 
(b) the extent to which the wrongful act may have furthered the employer's aims (and hence be more likely to have been committed by the employee);

(c) the extent to which the wrongful act was related to friction, confrontation or intimacy inherent in the employer's enterprise; the extent of power conferred on the employee in relation to the victim; the vulnerability of potential victims to wrongful exercise of the employee's power. ${ }^{\text {so }}$

4. When the party on which vicarious liability is sought to be imposed is a non-profit organization, policy rationales for vicarious liability are relatively weak and the connection between the enterprise risk and the sexual assault must be particularly strong."

The results in the Bazley and Jacobi cases may be instructive in considering the scope of employment issue. In Bazley the perpetrator was employed by a non-profit organization operating a residential care centre for troubled children. He was authorized to do everything that a parent would do in relation to the child victim, and total intervention in the child's life was within the employee's mandate. Though no negligence in hiring the perpetrator was suggested, his sexual assaults were still found to attract vicarious liability to the employer and thus should be within the "scope of employment" as that phrase is used in liability policies. The basis of liability was that in the circumstances of the parentlike relationship with a high degree of power, dependency, and intimacy a materially increased risk of sexual abuse was created, and the perpetrator was provided with unusual or special opportunity to engage in abuse.

On the other hand, in Jacobi the majority of the Court held that there should be no vicarious liability or, in other words, that the sexual abuse was not committed in the "scope of employment." The perpetrator was a program director for a non-profit boys and girls club. His job involved operating a recreational facility, supervising volunteer staff, organizing children's recreationalactivities, and occasionally participating in the same. He was also encouraged to form friendships and have positive rapport with the children at the club. The perpetrator met a brother and sister through the club and eventually sexually assaulted the male child and had sexual intercourse with the female child, both events occurring at his home and outside working hours. The majority considered it to be of critical importance that the perpetrator and the club did not stand in the place of a parent to the victims and that the incidents occurred away from the public club facilities, after working hours. A review of prior case law was held to be conclusive in showing that vicarious liability in such circumstances was beyond that suggested by any judicial consensus. Further, the circumstances also negated the requisite strong connection (particularly since the employer was a non-profit organization) between the "enterprise risk" inherent in the club activities and the sexual assaults. The requisite combination of power and intimacy was not created or even fostered by virtue of the perpetrator's employment, and thus the torts were not within the "scope of employment" so as to attract vicarious liability. 
In many cases sexual torts are alleged to have some connection to the workplace or operations of the employer of the perpetrator. It is probably fair to suggest that, because of the detailed examination of facts needed to determine the issue, it will often be difficult to convince a court at the defence stage that no defence is owed to an employee defendant on the basis that the alleged sexual torts clearly and unambiguously fall outside the scope of employment. However, when the alleged wrongful acts have only a tenuous connection to the employment on the basis of pleaded facts this type of argument may be convincing.

\section{INTENTIONAL ACTS EXCLUSIONS}

Liability coverage is invariably subject to an exclusion for bodily injury "caused intentionally," or through "intentional acts" of the insured, or that is "expected or intended from the standpoint of the insured." The operation of this standard exclusion in sexual torts will depend first on whether damages for sexual battery constitute "bodily injury," making the exclusion applicable, and second on whether the remainder of the exclusion is operative.

"Bodily injury" is generally defined to include bodily injury, sickness or disease..$^{52}$ Though there is considerable debate in the jurisprudence regarding the extent to which emotional distress, absent physical contact or interference with one's person, can constitute "bodily injury, sickness or disease," there is little or no real debate that all injuries caused by sexual battery, including psychological trauma, constitute "bodily injury." The issue was recently addressed by the British Columbia Court of Appeal in Wellington Guarantee v. Evangelical Lutheran Church in Canada. ${ }^{53}$ After reviewing the state of American law and prior Canadian cases, the Court held that, inter alia, nervous shock, depression, psychological injury, and mental distress resulting from sexual abuse of the plaintiff victims by their adoptive father were within the meaning of "bodily injury, sickness or disease." Though not dealing with the issue directly, the Supreme Court of Canada in Scalera proceeded on the assumption that "humiliation," "mental distress," "psychological and emotional trauma," and similar claims constituted "bodily injury." 54

The issue was also directly addressed in $W .-V .(T)$ v. $W .(K . R . J)^{55}$ where Reilly J., in dealing with a claim of sexual assault, stated:

It now seems beyond dispute that the psychological trauma claimed by the plaintiff falls within the definition of "bodily injury" for the purpose of this action. Even in the context of criminal jurisprudence, where the definition of "bodily harm" as "any hurt or injury" must be strictly construed in favour of the accused, those words have been found to include psychological harm. In R. v. McCraw, [1991] 3 S.C.R.

72 at p. 81,66 C.C.C. (3d) 517 at p. 524, Mr. Justice Cory, for a unanimous court stated: (Man. Q.B.) at 116-17.

s) Supra note 15.

54 Supra note 1.

ss (1996), 39 C.C.L.I. (2d) 272 (Ont. Gen. Div.) [hereinafter W. v. W.]. 
There can be no doubt that psychological harm may often be more pervasive and permanent in its effect than any physical harm. I can see no principle of interpretation nor any policy reason for excluding psychological harm from the scope of sec. $264.1(1)(a)$ of the Code. ${ }^{56}$

Where there is coverage for "personal injury" as well as for "bodily injury," arguments may be made that this other coverage applies, and the intentional act exclusion for bodily injury is therefore not applicable. Arguments in this respect should fail for two reasons. First, "personal injury" is a term of art in the insurance industry. It is distinct from, and should be considered mutually exclusive of "bodily injury," even if the definition in the policy is not so clear. These points were made by Hilliker in Liability Insurance Law in Canada:

In commercial liability policies the term "personal injury" is not used in its popular sense. Rather, insurers providing commercial liability insurance make a distinction between "bodily injury" and "personal injury," the latter term being used to refer to a variety of offences against the person, including defamation of character, false arrest and imprisonment, and discrimination..$^{57}$

Even when it is not specifically defined as being mutually exclusive to "bodily injury," "personal injury" will generally be defined in terms of the offences from which it might arise. These offences will deal with infringements of rights and damage to reputation (e.g., discrimination, defamation of character, false arrest) absent physical or emotional injury. They describe injuries different in quality than a "bodily injury," and by virtue of basic interpretive principles such as ejusdem generis ${ }^{58}$ and noscitur a sociis, ${ }^{59}$ "personal injury" should be limited to these types of losses. Equally important, narrowing the scope of "bodily injury" to exclude emotional trauma and giving "personal injury" a meaning broad enough to cover damages arising from sexual assaults could render the coverages and exclusions for "bodily injury" virtually superfluous (i.e., nearly all tort victims feel some sort of psychological distress). The fundamental interpretive rule that all parts of the policy must be given practical meaning would then be violated.

A second reason these arguments lack merit is that even where the scope of "personal injury" is considered sufficiently broad to encompass physical or psychological injuries from sexual assaults, those injuries will continue to constitute "bodily injuries" according to the standard policy definition as interpreted in case law (see cases cited above). Though they may also constitute "personal injury," such injuries should be subject to the standard intentional act exclusion for bodily injury based on the above analysis.

Having concluded that the injuries flowing from sexual battery constitute "bodily injury," the operation of the remainder of the exclusion can be considered. The standard exclusion for intentional conduct is the most common vehicle used by courts to enforce the uncertainty principle and deny coverage to perpetrators of sexual torts. Most

Ibid. at 279.

Supra note 34 at 197.

The general word is to be interpreted to include only things of the same type or nature as those things listed specifically.

The meaning of a word can be gathered from the words immediately surrounding it. 
prominently, the Supreme Court of Canada in Scalera and its companion case Sansalone v. Wawanesa Mutual Insurance $\mathrm{Co}^{60}$ utilized such an exclusion as a means to find that perpetrators of sexual assaults were not owed a defence under homeowner's policies. The Court was unanimous in both cases that an exclusion for bodily injury "caused by any intentional act or failure to act" required not only that the action causing the damage be intentional but that it be intended to cause injury. The Court then concluded that as a matter of legal inference non-consensual sexual contact imports such an intent. The same result should follow where the exclusion refers to bodily injury "expected or intended from the standpoint of the insured." Unless the perpetrator can somehow escape the applicability of this type of exclusion, it should operate to exclude a defence in sexual tort claims.

\section{CRIMINal ACt EXClusions}

"Personal injury" and professional liability cover is generally subject to an exclusion relating to criminal acts. Other types of coverage may also be subject to this type of exclusion. The standard CGL policy in Canada excludes "personal injury ... arising out of the wilful violation of a penal statute or ordinance committed by or with the consent of the insured." W1 Wording excluding coverage for damages resulting from "criminal acts" is also common. Regardless of the wording, this type of exclusion may also remove any coverage related to sexual torts. Section 265 of the Criminal Code provides that a criminal assault occurs when force is applied to another person for sexual purposes, directly or indirectly, without that person's consent. ${ }^{62}$ Both criminal and civil assault depend on lack of consent, though one has a purely objective test, and the other requires mens rea. Unless there are some facts to legitimately suggest an honest but negligent belief in consent by the perpetrator, the sexual act, in order to be actionable, must also be criminal. It may be possible in some circumstances for a court to find that a plea of sexual battery did not, by necessity, involve the requisite elements of a criminal offence, and the duty to defend and indemnify may thus not be excluded as a criminal act in some civil sexual tort cases. However, where an honest, negligent belief in consent is not specifically pleaded, the exclusion should operate to exclude defence obligations.

\section{ERRORS AND OMISSIONS}

Professional liability coverage is generally framed in terms of "errors and omissions." These very words should be sufficient, absent reliance on any exclusion, to place a perpetrator's liability for sexual torts beyond coverage. The leading case suggesting this outcome is Haseldine v. Hosken. ${ }^{63}$ A solicitor's indemnity policy insured against "neglect, omission or error" while acting in a professional capacity. The solicitor willingly entered into a champertous agreement without realizing it was champertous. The English Court of Appeal unanimously held that liability arising from this champerty did not come

60

61

62

6]

[2000] I S.C.R. 627.

This definition is taken from IBC Form 2100 (March 2000).

R.S.C. 1985, c. C-46. Section 265(1)(a) reads "[a] a person commits an assault when (a) without the consent of another person, he applies force intentionally to that other person, directly or indirectly." [1933] 1 K.B. 822 (C.A.). 
within the meaning of "neglect, omission or error" and was therefore not covered. Scrutton L.J., in considering the nature of the cover provided, stated:

It is puzzling to know what the neglect, omission or error was. Mr. Haseldine knew what he was doing in the sense that he made the agreements which clearly expressed what he intended. It is quite true that he appears to have been unaware that what he was doing was illegal or that he was committing a criminal offence; that, however, is not the kind of neglect, omission or error contemplated by the policy. ${ }^{\text {st }}$

Another discussion on this subject reacheda similar conclusion in West Wake Price \& Co. v. Ching. ${ }^{65}$ Unfortunately, there do not appear to be any cases applying this logic in the sexual tort context nor any Canadian authorities on the general point that a covered claim must not arise from an intentional act. Even absent specific case law authority, the argument against coverage for a perpetrator should still be a strong one. One cannot normally commit a sexual act without intending to commit that act, and so it would appear that such could not constitute an "error or omission" within the proper meaning of those words. It is difficult to conceive of exactly what the "error or omission" could be in such circumstances.

\section{PUBlic POLICY}

Even if there are no policy provisions which explicitly exclude liability for sexual torts or which can be successfully argued to do so implicitly, an insurer can fall back on public policy and the related doctrine of reasonable expectations to imply an exclusion for intentionally caused harm. In Scalera Iacobucci J. referred extensively to the doctrine of reasonable expectations. In the introductory portion of his reasons, he quoted approvingly from the judgment of Estey J. in Consolidated-Bathurst wherein Estey J. stated:

Similarly, an interpretation which defeats the intentions of the parties and their objective in entering into the commercial transaction in the first place should be discarded in favour of an interpretation of the policy which promotes a sensible commercial result. ... Said another way, the Courts should be loath to support a construction which would either enable the insurer to pocket the premium without risk or the insured to achieve a recovery which could neither be sensibly sought nor anticipated at the time of the contract. ${ }^{\text {so }}$

Later, when justifying denial of a defence to the perpetrator of sexual battery in Scalera, Iacobucci J. again cited reasonable expectations in the concluding portions of his judgment, quoting part of Rodriguez v. Williams: "The average person purchasing homeowner's insurance would cringe at the very suggestion that [the person] was paying for such coverage. And certainly [the person] would not want to share that type of risk with other homeowner's policy holders." ${ }^{, 67}$

Supra note 2 at 58, cited with approval in Scalera, supra note 1 at 592, para. 71. 
Iacobucci J. agreed that even a policyholder would not normally expect the insurer to defend an action against the insured for failing to pay for damages alleged to have been caused by the sexual misconduct of that insured.

These reasonable expectations and the public policy arguments against compensating a tortfeasor for an intentional wrong support an implied term to any insurance denying defence and indemnity to alleged perpetrators of sexual misconduct. Brown and Menezes, setting out the basic purpose of insurance, seem to endorse such an implied exclusion for intentionally caused harm on this basis: "It follows, therefore, that even where the literal wording of a policy might appear to cover certain losses, it does not, in fact, do so, if ... it results from the intentional actions of the insured."68 Iacobucci J. endorsed this very passage in Scalera, ${ }^{69}$ though it was not considered necessary to rely on any implied exclusion in that case. Nonetheless, the reasons in Scalera should provide strong ammunition for such an argument in an appropriate future case.

\section{POSSIBILITY OF COVERAGE - INNOCENT CO-INSUREDS}

When civil claims for sexual torts are made, persons other than the perpetrators are often sued for negligence, breach of fiduciary duty, and other causes of action. When a sexual tort has any connection whatsoever to employment, the employer of the perpetrator is almost invariably sued. The employer can attract direct liability by virtue of negligence in hiring employees without adequate training, supervision, or background checks. The standard of care for an employer may indeed be quite high in these respects, particularly where care of children is involved. Vicarious liability may also be imposed when the perpetrator has been acting within the "scope of employment." As discussed above in the context of when an employee is an "insured" under a liability policy, the law in this area has recently been revisited by the Supreme Court of Canada, resulting in broadened criteria for imposing vicarious liability.

An innocent co-insured under a liability policy may be covered for damages arising from sexual tort claims when the liability is direct by virtue of negligence, breach of fiduciary duty, or otherwise, and where vicarious liability is imposed. ${ }^{70}$ Most policy provisions will speak of "the insured," and many will also have provisions specifically providing that the insurance applies separately to each insured against whom a claim is made. In these circumstances, coverage will be considered separable, such that coverage or lack thereof for "the insured" who has committed the wrongful acts will not affect the coverage of innocent co-insureds. However, the policy may not always be so clear. Absent a specific exclusion for sexual torts applying to all insureds, this issue may hinge on whether the exclusions and other policy wordings relevant to the perpetrator refer to "the insured" or "an insured."

30 See for example, Mcleod v. Tecorp International, 865 P.2d 1283 (Or. 1993); Seminole Point Hosp. Corp. v. Aetna Casualty and Surety, 675 F.Supp. 44 (D.N.H. 1987); and Ranger Insurance Company v. American Mutual Protection Bureau, [1992] U.S. Dist. LEXIS 13578 (N.D. Cal) online: LEXIS (genfed, 9 DIST). 
In $W$. v. $W .^{n}$ a daughter alleged that she had been sexually assaulted by her stepfather. She also brought action against her mother for not preventing the assaults. Over the period of years in which the assaults took place the defendants were covered under various homeowner's policies. While the first policy of insurance excluded "bodily injury caused intentionally by or at the direction of an insured," the second policy excluded "bodily injury caused intentionally by or at the direction of the insured." The Court found that under the first policy the mother was not owed a defence, but under the second policy she was owed a defence. The Court reasoned:

I conclude that "an insured" must be given its ordinary, common-sense meaning. "An" is an indefinite article, and it means "any" insured. Therefore, intentional conduct by W., or any other insured, excludes the obligation to indemnify on the part of the insurer. There is abundant American jurisprudence to support this conclusion....

However, "the" is a definite article, and does not mean, nor can it be equated with the indefinite article "an," nor with the adjective 'any', both of which are used to modify "insured" in other paragraphs of the exclusion clause.... Reference to "the insured" in an exclusion clause has generally been held in the American jurisprudence to mean 'the insured making the claim', or at the very least to be ambiguous. ${ }^{2}$

For further authority on the point, one could cite Rankin v. North Waterloo Farmers Mutual Insurance Co., ${ }^{73}$ Jupp v. Firth and Westminister Mutual Fire Insurance Co. ${ }^{74}$ the leading American cases of Allstate Insurance Co. v. Freeman, ${ }^{75}$ State Farm Fire and Casualty Co. v. Davis, ${ }^{76}$ and Unigard Mutual Insurance Co. v. Argonaut Insurance Co. $^{77}$

At first reading, the Supreme Court of Canada decision in Scott v. Wawanesa Mutual Insurance $\mathrm{Co}^{78}$ might suggest an even more stringent approach to coverage. Specifically, the Scott case could be taken to indicate that even where the relevant policy wording refers to "the insured" it should be taken as equivalent to "any insured." However, this case arose in circumstances where the interests of the insureds were "inseparably connected," a fact which was considered of vital importance. ${ }^{79}$ In Scott one insured intentionally burned down a home, the subject matter of the insurance. The Court held that the policy need not respond to the claims of any insured, though the relevant policy exclusion referred to a "criminal or wilful act or omission of the Insured." in $W$. v. W. distinguished Scott in that it was based on a common proprietary interest among the innocent and guilty co-insureds. ${ }^{81}$ At least one text ${ }^{82}$ has also suggested that

Supra note 55.

Ibid. at 280-81.

(1979), 25 O.R. (2d) 102 (C.A.).

(6 January 1993), London 1493A (Ont. Gen. Div.).

443 N.W. 2d 734 (Mich. 1989).

612 So. 2d 458 (Ala. 1993).

579 P. 2d 1015 (Wash. App. 1978).

(1989), 59 D.L.R. (4th) 660 [hereinafter Scott].

Ibid. at 676.

Ibid. at 662.

Supra note 55 at 286.

M. Snowden \& M. Lichty, Annotated Commercial General Liability Policy, Looseleaf (Aurora:

Canada Law Book Inc., 1997) at 14-24 to 14-30. 
the rationale in Scott should be restricted to cases where the coverage involved is first party (i.e., property) as opposed to third party (i.e., liability) cover. This makes sense in first party cases where all insureds have a proprietary insurable interest and stand to benefit (or at least not lose out) through intentional destruction of the insured property. On the other hand, the innocent co-insured in a sexual tort claim gains no benefit from the perpetrator's act, and the perpetrator will not directly benefit from the co-insured's coverage.

Though it does not specifically refer to either $W$. v. $W$. or Scott, the recent British Columbia Court of Appeal decision in Bluebird Cabs Ltd. v. Guardian Insurance Co. of Canada ${ }^{83}$ is consistent with this view. The employer of cab drivers accused of sexual battery sought a defence where vicarious liability was alleged. The relevant policy provisions spoke of "the insured," and the policy also contained a provision providing that all rights and duties under the policy apply separately to each insured against whom a claim or action was brought. The Court ruled that since no fault or intention was to be inferred against the employer by virtue of any vicarious liability, the alleged bodily injury was not "expected or intended" from the standpoint of the employer, and a defence was therefore owed by the insurer. In other words, if the wrongful acts are not intended from the standpoint of the insured seeking cover a defence will be owed. Under this reasoning, it is difficult to imagine how an employer would not be owed a defence when sexual torts are alleged against an employee.

One further potential justification for providing a defence to a negligent or vicariously liable employer or other co-insured is the reasonable expectations of the parties to the insurance contract. A consumer would probably be held to expect coverage for vicarious liability and negligence in all circumstances unless specifically excluded, including sexual tort claims. Using the terminology of Brown and Menezes, ${ }^{84}$ the liability from that person's perspective is both fortuitous and contingent, and coverage is consistent with the fundamental uncertainty or risk principle that forms the foundation for liability insurance. A person would reasonably expect to be governed by this principle. The remarks of Iacobucci J. in Scalera concerning reasonable expectations and basic insurance ${ }^{85}$ also lend some support to this argument.

\section{Conclusions}

The recent decision of the Supreme Court of Canada in Scalera has significantly clarified the law regarding the duty to defend, particularly with respect to coverage for sexual torts. In general terms, the most significant facet of the decision is the introduction of a new element to the test of an insurer's duty to defend. The new requirement is that potentially covered causes of action must not be "derivative" of the excluded claims; in the case of sexual torts, those are claims for intentionally caused harm. This requirement has great significance to sexual torts where intentional sexual acts may also feature aspects of negligence or constitute breaches of fiduciary or contractual duties. Clearly, the aim of

8s Supra note 1 at 623-24, paras. 134-35. 
the Supreme Court of Canada in adding this new requirement to the duty to defend analysis is to discourage manipulative, vague pleadings that are designed strictly to permit access to insurance money and to give lower courts some guidance and ammunition with which to render such practice ineffective.

On a practical level, the following conclusions can probably be safely drawn from Scalera and relied upon in all but the most exceptional or unusual sexual tort cases:

1. In order to be actionable, sexual activity must have been non-consensual, with consent being determined on an objective basis;

2. Such non-consensual sexual acts, by their very nature, involve an intent by the perpetrator to injure the victim, and all the resulting injuries will have been considered to be caused intentionally;

3. While there may be negligent aspects to actionable sexual conduct (such as negligent misrepresentations) such negligence will be considered derivative of the intentional actions of the insured in engaging in the non-consensual sexual activities;

4. Pleadings that the non-consensual sexual acts constitute breaches of fiduciary duty or breaches of contract will be ineffective actions on which to base a possibility of coverage. Such pleadings change neither the nature of the intentional acts nor that the resulting injuries are caused intentionally by the perpetrator. In any event, such causes of action will be derivative of the nonconsensual acts if they arise from these very acts and thus may not be the basis for any duty to defend;

5. Absent specific policy language to the contrary, alleged perpetrators of sexual assaults will not be owed any defence obligations from liability insurers, whether under homeowner's policies, CGL policies, or otherwise. There are a number of standard liability coverage requirements and exclusions that should yield this result. Even in the absence of any specific policy provisions, a court is likely justified in implying such an exclusion;

6. Innocent co-insureds (while perhaps negligent in safeguarding the victim's personal well-being) who are not themselves perpetrators will be owed a defence if the relevant policy exclusions refer to "the insured" rather than "an insured." Under the latter wording it is likely that no duty to defend an innocent coinsured will be found.

Though not addressed in Scalera, the current state of the law regarding coverage for innocent co-insureds in sexual tort cases seems to support this final conclusion.

Perhaps the most important message to be taken from the Scalera decision is the primacy of the concept of uncertainty in determining an insurer's defence obligations. This guiding principle was stressed repeatedly by lacobucci J. in his reasons in Scalera, most 
notably in considering the doctrine of reasonable expectations. Future sexual tort cases will undoubtedly feature attempts by insured perpetrators to distinguish Scalera on the facts. The insurance industry and the courts should be prepared to consider and evaluate these future arguments using this uncertainty principle as the ultimate guide. 